\title{
Structure and function of large arteries in hypertension in relation to oxidative stress markers
}

\author{
Łukasz Klima ${ }^{1}$, Kalina Kawecka-Jaszcz ${ }^{1}$, Katarzyna Stolarz-Skrzypek ${ }^{1}$, Jan Menne ${ }^{2}$, Kamil Fijorek ${ }^{3}$,

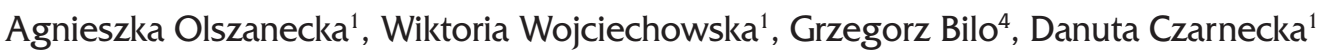 \\ $11^{\text {st }}$ Department of Cardiology and Hypertension, Jagiellonian University Medical College, Krakow, Poland \\ ${ }^{2}$ Clinic for Nephrology, Hanover Medical College, Hanover, Germany \\ ${ }^{3}$ Department of Statistics, Krakow University of Economics, Krakow, Poland \\ ${ }^{4}$ Department of Cardiology, The Italian Institute for Auxology, Milan, Italy
}

\begin{abstract}
Background: The relationship between hypertension and oxidative stress remains unexplained. Nevertheless, it is well established that reactive oxygen species have an influence on the arterial wall, endothelial function and therefore determine blood pressure.

Aim: The evaluation of selected oxidative stress markers in hypertensive patients and an assessment of the relationship between oxidative stress markers and the arterial structure and function. We also aimed to investigate whether the influence of oxidative stress on remodelling of arteries, their structural and functional changes is independent of hypertension or is related to hypertension.

Methods: Altogether 217 subjects (114 female, 103 male) were enrolled from hypertensive families. The mean age was $45.5 \pm 16$ years, and the group included 155 hypertensives. In every subject, the pulse wave velocity and intima-media thickness (IMT) in carotid arteries were measured as well as selected oxidative stress markers such as asymmetric dimethylarginin (ADMA), symmetric dimethylarginin (SDMA), advanced oxidation protein products (AOPP) and oxidised low density lipoproteins (ox-LDL).

Results: The results of multivariate analysis show that in hypertensive patients: the ADMA level increased with increasing peripheral pulse pressure $(b=0.003 ; p<0.001)$, and AOPP was related to higher carotid IMT $(b=0.91 ; p=0.036)$. In normotensive subjects, the following associations were found: between ADMA and central pulse pressure $(b=0.006$; $p=0.008)$, between SDMA and the peripheral augmentation index $(b=-0.03 ; p=0.014)$, between AOPP and the peripheral augmentation index $(b=0.011 ; p=0.04)$, and between ox-LDL/LDL ratio and the peripheral augmentation index $(b=-0.025 ; p=0.004)$. The SDMA/ADMA ratio was associated with estimated glomerular filtration rate in both groups $(b=-0.0061 ; p<0.0001$ and $b=-0.005 ; p<0.017$, respectively). In hypertensives, we observed a relation with peripheral pulse pressure $(b=-0.0067 ; p=0.0143)$. Moreover, in normotensives there was an association between the SDMA/ADMA ratio and uric acid $(b=1.3629 ; p=0.046)$

Conclusions: We found that the influence of oxidative stress on the structure and function of large arteries was independent of hypertension. Therefore oxidative stress may play a significant role in the development of arterial stiffness. Higher oxidative stress is associated with more advanced arterial remodelling in hypertension.
\end{abstract}

Key words: oxidative stress, arterial stiffness, hypertension

Kardiol Pol 2013; 71, 9: 917-923

\section{INTRODUCTION}

Hypertension (HT) is one of the commonest cardiovascular risk factors and the leading cause (32\%) of death in Poland [1].
Severe complications of HT and its high prevalence have made primary prevention and early diagnosis a priority for healthcare services worldwide.

\section{Address for correspondence:}

Łukasz Klima, MD, PhD, $1^{\text {st }}$ Department of Cardiology and Hypertension, Jagiellonian University Medical College, ul. Kopernika 17, 31-501 Kraków, Poland, tel: +48 1242473 00, e-mail: Iklima@su.krakow.pl Received: 23.08.2012 Accepted: 06.03.2013

Copyright (C) Polskie Towarzystwo Kardiologiczne 
Recent studies have suggested that oxidative stress plays some role in the functioning and structure of the arteries. Elevated reactive oxygen species (ROS) leads to increased resistance of the arteries due to the reduction of nitric oxide (NO) availability, the peroxidation of membrane lipids, the impairment of relaxation, and the stimulated proliferation of smooth muscle cells. Elevated blood pressure (BP), on the other hand, caused by angiotensin II, xanthine oxidase, mechanical stress increases ROS activation and leads to the impairment of the endothelial function.

The main factor influencing endothelial function is NO. Its production depends on the availability of a cofactor for NO synthase such as tetrahydrobiopterin and endogenous competitive inhibitors of NOS such as asymmetric dimethylarginin (ADMA) or N-monomethylarginin (L-NMMA). The correlation between ADMA and BP has been proven [2]. Weber et al. [3] discovered that the ADMA level in serum is related to the central augmentation index. They evaluated the quantitative relationship between plasma levels of ADMA and arterial wave reflection assessed by pulse wave analysis technique as well as aortic pulse wave velocity (PWV) measured invasively during coronary angiography.

PWV and the distance of reflection points to the heart are the main determinants of the peripheral and central augmentation indices. Wave reflection occurs at sites of changes of arterial impedence along the arterial tree, such as branching points or atherosclerotic plaques. The peripheral and central augmentation indices increase with age and mean arterial pressure and are inversely related to heart rate and body height. Augmentation index predicts clinical events independently of peripheral pressures. As diagnostic thresholds, the following values have been proposed for middle-aged men (i.e. 40 years and above): 90\% for the peripheral augmentation index, and 30\% for the central augmentation index [4].

Zoccali et al. [5] found that ADMA was an independent predictor of carotid intima-media thickness (IMT) thickening. In the case of another oxidative stress marker (oxidised low density lipoproteins — ox-LDL), it also affects BP because it interacts with the RAA system [6]. Advanced oxidation protein products (AOPP) are considered a risk factor of atherosclerosis and coronary artery disease (CAD) [7]. Lower concentrations of symmetric dimethylarginin (SDMA) that are commonly found in serum, do not inhibit NOS, therefore it was considered an insignificant substance until Kiechl et al. [8] revealed that ADMA is not a better marker than SDMA for cardiovascular risk. Family predisposition to the development of HT may be manifested by exacerbated oxidative stress, and this leads to changes in the arterial wall even before HT develops.

The relationship between oxidative stress and $\mathrm{HT}$ remains still unexplained. It is considered to be a vicious circle of reactive oxygen species - that are both cause and result of HT. Thus the aim of this study was to assess selected oxidative stress markers in HT and normotensive subjects, and to analyse their relationship with the parameters of the arterial structure and function while adjusting for confounders. We also aimed to investigate whether the influence of oxidative stress on remodelling of arteries, their structural and functional changes is independent of HT or related to HT.

\section{METHODS}

The study was conducted within the framework of The InGenious HyperCare Network of Excellence [9]. Subjects were recruited from the Outpatient Hypertensive Clinic at the $1^{\text {st }}$ Department of Cardiology and Hypertension, Jagiellonian University Medical College. Then their family members were enrolled - at least three people from two generations. We recruited 50 families, with altogether 217 subjects (114 women, 103 men). All participants signed a form which gave their informed consent. The protocol of the study was approved by the Bioethics Committee at the Jagiellonian University in Krakow.

Office BP measurement was performed according to the ESH guidelines [10]. Peripheral pulse pressure was defined as the difference between the mean systolic (SBP) and diastolic (DBP) office blood pressure.

In every subject, 24-h ambulatory blood pressure monitoring (ABPM) was performed with SpaceLabs 90207 (Redmont, WA, USA) with measurements every 15 min during the day (between 6 a.m. and 10 p.m.) and every 20 min at night. We adopted the criteria for incorrect measurements introduced by Staessen et al. [11].

Aortic PWV was evaluated with a Sphygmocor ${ }^{\circledR}$ device. The pulse wave on the carotid and femoral artery was recorded, then on the carotid and radial artery. The distance between the recording points and the sternal notch was measured and PWV was calculated as a fraction of the distance and foot-to-foot time.

For pulse wave analysis after 5 min rest in the supine position, the pulse wave on the radial artery was recorded with a microtip pressure transducer (Model SPT-301, Millar Instruments, Houston, TX, USA) and with Sphygmocor ${ }^{\circledR}$ software (ver. 6.31 AtCor Medical Pty., Ltd., Australia). After recording the radial pulse wave, the central BP wave was obtained and the peripheral and central augmentation indices (Alx $\mathrm{p} \mathrm{[ \% ]} \mathrm{and}$ Alx c [\%], respectively) were calculated. Peripheral Alx was defined as the quotient of the second (P2) and first (P1) peak of SBP. The central Alx was defined as the difference between P2 and P1 divided by the central pulse pressure (PP C).

For the evaluation of structural changes in the arterial wall, ultrasonography of the carotid arteries was performed using a two-dimensional projection along a longitudinal axis with $10 \mathrm{MHz}$ probe and a Vivid 7 PRO GE device. The IMT was measured $2 \mathrm{~cm}$ proximally from the bulb of the common carotid artery and its bifurcation on far wall with semiautomatic method provided with GE software.

\section{Laboratory tests}

We collected fasting blood samples for measurements of the following parameters: glucose, cholesterol, low density lipoprotein cholesterol (LDL-C), high density lipoprotein 
Table 1. Characteristics of the study population

\begin{tabular}{|c|c|c|c|}
\hline & $\begin{array}{c}\text { Hypertensives } \\
\mathrm{N}=155 \text { (71.4\%) } \\
\text { Men/women: } 74 / 81\end{array}$ & $\begin{array}{c}\text { Normotensives } \\
\mathrm{N}=62(28.6 \%) \\
\text { Men/women: } 29 / 33\end{array}$ & $\mathbf{P}$ \\
\hline Age [years] & $48.95 \pm 15.19$ & $36.98 \pm 14.73$ & $<0.001$ \\
\hline Height [cm] & $168.80 \pm 9.28$ & $169.23 \pm 9.04$ & 0.7563 \\
\hline Weight [kg] & $81.29 \pm 14.69$ & $70.28 \pm 14.43$ & $<0.001$ \\
\hline Body mass index $\left[\mathrm{kg} / \mathrm{m}^{2}\right]$ & $28.47 \pm 4.26$ & $24.43 \pm 3.99$ & $<0.001$ \\
\hline Waist to hip ratio & $0.89 \pm 0.08$ & $0.85 \pm 0.09$ & $<0.001$ \\
\hline $\mathrm{SBP}[\mathrm{mm} \mathrm{Hg}]$ & $144.15 \pm 22.11$ & $127.64 \pm 11.89$ & $<0.001$ \\
\hline $\mathrm{DBP}[\mathrm{mm} \mathrm{Hg}]$ & $85.87 \pm 11.69$ & $78.86 \pm 8.49$ & $<0.001$ \\
\hline HR [bpm] & $72.82 \pm 11.62$ & $74.31 \pm 9.30$ & 0.3235 \\
\hline Glucose $[\mathrm{mmol} / \mathrm{L}]$ & $5.42 \pm 1.30$ & $4.94 \pm 0.66$ & $<0.001$ \\
\hline $\mathrm{LDL}-\mathrm{C}[\mathrm{mmol} / \mathrm{l}]$ & $2.99 \pm 0.90$ & $2.82 \pm 0.97$ & 0.97 \\
\hline Cholesterol [mmol/L] & $5.17 \pm 1.05$ & $4.87 \pm 1.19$ & 0.0867 \\
\hline $\mathrm{HDL}-\mathrm{C}[\mathrm{mmol} / \mathrm{L}]$ & $1.43 \pm 0.37$ & $1.61 \pm 0.39$ & 0.0021 \\
\hline Triglycerides [mmol/L] & $1.70 \pm 0.93$ & $1.12 \pm 0.60$ & $<0.001$ \\
\hline $\mathrm{eGFR}\left[\mathrm{mL} / \mathrm{min} / 1.73 \mathrm{~m}^{2}\right]$ & $100.41 \pm 21.82$ & $116.07 \pm 26.20$ & $<0.001$ \\
\hline $24 \mathrm{~h} \mathrm{DBP}[\mathrm{mm} \mathrm{Hg}]$ & $77.10 \pm 9.05$ & $72.92 \pm 6.71$ & $<0.001$ \\
\hline $24 \mathrm{~h} \mathrm{SBP}[\mathrm{mm} \mathrm{Hg}]$ & $126.77 \pm 11.38$ & $119.85 \pm 8.43$ & $<0.001$ \\
\hline $24 \mathrm{~h} \mathrm{HR}$ [bpm] & $71.17 \pm 9.69$ & $76.11 \pm 8.24$ & $<0.001$ \\
\hline
\end{tabular}

Data is shown as mean \pm SD; $24 \mathrm{~h}$ DBP, SBP, HR $-24 \mathrm{~h}$ ABPM parameters respectively systolic, diastolic blood pressure and mean heart rate; eGFR - estimated glomerular filtration rate; HDL — high density lipoprotein cholesterol; LDL — low density lipoprotein cholesterol

cholesterol (HDL-C), triglycerides, creatinine, and uric acid. Repeated morning urine samples were collected to measure albumin and creatinine in urine. Selected oxidative stress markers were assessed: ADMA, SDMA and ox-LDL with ELISA tests and AOPP with spectroscopic analysis.

\section{Statistical analysis}

All statistical analyses were performed with STATISTICA 9.1 software and R 2.13. Continuous variables were presented as means with standard deviation. Categorical variables were presented as numbers and percentages. The Shapiro-Wilk test was used to assess the normality of continuous variables. The AOPP and ox-LDL/LDL ratio were logarithmically $(\log 10)$ transformed. To examine differences between two independent groups, the Student's t-test was used. The Fischer exact or $\chi^{2}$ tests were used to compare categorical variables. The unadjusted associations between continuous variables were examined by Pearson's or Spearman's correlation coefficient as appropriate. The association between variables adjusted for confounders was examined by stepwise multivariate regression. Two sided p-values $<0.05$ were considered statistically significant.

\section{RESULTS}

\section{Group characteristics}

In our group of 50 families, the most prevalent family structure consisted of a subject and his/her parents and one sib- ling (20 families). The second most common structure was a subject, one parent and two siblings (six families). The study population characteristics are summarised in Table 1. Normotensives $(n=62)$ compared to hypertensives $(n=155)$ were younger, had lower body mass index (BMI) and waist to hip ratio (WHR), lower glucose and triglyceride level, and higher HDL-C. Hypertensives had a lower estimated glomerular filtration rate (eGFR). Night-time DBP decrease was significantly more pronounced in normotensives.

Selected arterial parameters which differ between the groups of hypertensive and normotensive subjects are presented in Table 2.

The levels of oxidative stress markers did not differ between men and women with the exception of AOPPs which were higher in men (3.69 \pm 0.96 vs. $3.4 \pm 0.9 \mu \mathrm{mol} / \mathrm{L} ; \mathrm{p}=0.027)$.

In the hypertensive group, angiotensin converting enzyme (ACE) inhibitors were administered in 71 patients and angiotensin receptor blockers (ARB) in 25 . Thus, $62 \%$ of hypertensive subjects were treated with drugs with a strong influence on oxidative stress [12]. Moreover beta-blockers were administered in 61, calcium channel blockers in 46 and diuretics in 74 patients, whereas statins were administered in 28 patients.

\section{Multivariate analysis}

We did not observe any significant differences in ADMA, SDMA, AOPP or ox-LDL between normotensives and hyper- 
Table 2. Arterial stiffness parameters

\begin{tabular}{lccc} 
& Hypertensives & Normotensives & $\mathbf{P}$ \\
& $\mathbf{N}=\mathbf{1 5 5}(\mathbf{7 1 . 4 \% )}$ & $\mathbf{N}=\mathbf{6 2}(\mathbf{2 8 . 6 \% )}$ & 0.004 \\
PWV (c-r) $[\mathrm{cm} / \mathrm{s}]$ & $841.51 \pm 139.58$ & $785.48 \pm 119.18$ & $<0.001$ \\
PWV (c-f) [cm/s] & $881.19 \pm 217.89$ & $745.13 \pm 158.27$ & $<0.001$ \\
IMT [mm] & $0.63 \pm 0.16$ & $0.53 \pm 0.13$ & $<0.001$ \\
Alx p [\%] & $79.11 \pm 24.22$ & $60.23 \pm 20.54$ & $<0.001$ \\
Alx c [\%] & $23.38 \pm 16.32$ & $10.93 \pm 16.23$ & 0.0046 \\
PP p [mm Hg] & $57.58 \pm 13.37$ & $52.34 \pm 11.44$ & $<0.001$ \\
PP c [mm Hg] & $44.45 \pm 12.64$ & $35.36 \pm 9.63$ & \\
\hline
\end{tabular}

Data is shown as mean \pm SD; PWC c-r — carotid radial pulse wave velocity; PWV c-f — carotid femoral pulse wave velocity; IMT — intima-media thickness; Alx $\mathrm{p}$ - peripheral augmentation index; Alx c — central augmentation index; PP p — peripheral pulse pressure; PP $\mathrm{c}$ - central pulse pressure

Table 3. Oxidative stress markers

\begin{tabular}{lccc} 
& Hypertensives & Normotensives & $\mathbf{P}$ \\
& $\mathbf{N}=\mathbf{1 5 5}(\mathbf{7 1 . 4 \% )}$ & $\mathbf{N}=\mathbf{6 2} \mathbf{( 2 8 . 6 \% )}$ & 0.4989 \\
ADMA $[\mu \mathrm{mol} / \mathrm{L}]$ & $0.56 \pm 0.16$ & $0.58 \pm 0.17$ & 0.4287 \\
SDMA $[\mu \mathrm{mol} / \mathrm{L}]$ & $0.74 \pm 0.20$ & $0.71 \pm 0.17$ & 0.9983 \\
Log $(A O P P)[\mu \mathrm{mol} / \mathrm{L}]$ & $3.54 \pm 0.96$ & $3.54 \pm 0.90$ & 0.9425 \\
Log $(\mathrm{ox}-\mathrm{LDL} / \mathrm{LDL})[\mathrm{ng} / \mathrm{mL} / \mathrm{mmol} / \mathrm{L}]$ & $4.18 \pm 1.25$ & $4.19 \pm 1.25$ & 0.223 \\
SDMA/ADMA & $1.40 \pm 0.53$ & $1.31 \pm 0.45$ & \\
\hline
\end{tabular}

Data is shown as mean \pm SD; ADMA — asymmetric dimethylarginin; SDMA — symmetric dimethylarginin; ox-LDL — oxidised low density lipoproteins; AOPP — advanced oxidation protein products

Table 4. Determinants of oxidative stress markers in hypertensive patients: multivariate analysis

\begin{tabular}{|c|c|c|c|c|c|c|c|c|c|c|}
\hline & \multicolumn{2}{|c|}{ ADMA } & \multicolumn{2}{|c|}{ SDMA } & \multicolumn{2}{|c|}{ Log (AOPP) } & \multicolumn{2}{|c|}{ Log (ox-LDL/LDL) } & \multicolumn{2}{|c|}{ SDMA/ADMA } \\
\hline & b & $p$ & b & $p$ & b & $p$ & b & $p$ & b & $p$ \\
\hline Intercept & 0.2818 & 0.0002 & 1.0000 & 0.0000 & 2.4406 & 0.0000 & 6.2664 & 0.0000 & 2.3534 & $<0.001$ \\
\hline Hypertension & -0.0199 & 0.4516 & -0.0047 & 0.8841 & -0.2059 & 0.1740 & 0.1604 & 0.4272 & 0.0542 & 0.5147 \\
\hline BMI & NS & NS & -0.0064 & 0.0489 & NS & NS & NS & NS & NS & NS \\
\hline Uric acid & NS & NS & 0.4495 & 0.0089 & 2.6258 & 0.0018 & NS & NS & NS & NS \\
\hline eGFR & 0.0012 & 0.0171 & -0.0023 & 0.0001 & NS & NS & NS & NS & -0.006 & $<0.001$ \\
\hline Ex-smoker & NS & NS & NS & NS & -0.4052 & 0.0104 & NS & NS & NS & NS \\
\hline IMT & NS & NS & NS & NS & 0.9108 & 0.0368 & NS & NS & NS & NS \\
\hline PP p & 0.0031 & 0.0005 & NS & NS & NS & NS & NS & NS & -0.0067 & 0.0143 \\
\hline DBP & NS & NS & NS & NS & NS & NS & -0.026 & 0.001 & NS & NS \\
\hline
\end{tabular}

Additional variables included in multivariate analysis: age, waist to hip ratio and gender were non-significant; ADMA — asymmetric dimethylarginin; SDMA — symmetric dimethylarginin; ox-LDL — oxidised low density lipoproteins; AOPP — advanced oxidation protein products; IMT — intima-media thickness; $b$ - regression coefficient; PP $\mathrm{p}$ — peripheral pulse pressure; PP c — central pulse pressure; BMI — body mass index; eGFR — estimated glomerular filtration rate; DBP — diastolic blood pressure; NS — non-significant

tensives after adjusting for potential confounders, i.e. age, BMI, WHR, uric acid, eGFR, sex, smoking, PWV, IMT, AIx, office BP in standard measurements and ABPM. The details are presented in Table 3. Correlations are related to office BP.

Using multivariate analysis, we found that in hypertensive patients (Table 4), ADMA was independently related to eGFR and the peripheral pulse pressure $(b=0.003 ; p<0.001)$.
SDMA showed a positive correlation to uric acid and a negative correlation to eGFR. AOPPs were significantly correlated to IMT ( $b=0.91 ; p=0.036)$ and uric acid. Ox-LDL/LDL ratio had a negative relation to DBP.

In normotensives, an association between ADMA and eGFR and the central pulse pressure $(b=0.006 ; p=0.008)$ was observed. SDMA was related to the peripheral Alx 
Table 5. Family hypertension burden and oxidative stress

\begin{tabular}{lccc|} 
& 1 relative & $\geq 2$ relatives & P \\
\hline ADMA $[\mu \mathrm{mol} / \mathrm{L}]$ & $0.57 \pm 0.16$ & $0.58 \pm 0.17$ & 0.7362 \\
SDMA $[\mu \mathrm{mol} / \mathrm{L}]$ & $0.71 \pm 0.17$ & $0.72 \pm 0.18$ & 0.8270 \\
$\log (\mathrm{AOPP})[\mu \mathrm{mol} / \mathrm{L}]$ & $3.33 \pm 1.07$ & $3.62 \pm 0.84$ & 0.3748 \\
Log $(\mathrm{ox}-\mathrm{LDL} / \mathrm{LDL})[\mathrm{ng} / \mathrm{mL} / \mathrm{mmol} / \mathrm{L}]$ & $3.88 \pm 1.38$ & $4.31 \pm 1.21$ & 0.3024 \\
SDMA/ADMA & $1.32 \pm 046$ & $1.32 \pm 0.45$ & 0.9862 \\
\hline
\end{tabular}

Data is shown as mean \pm SD; abbreviations as in Table 3

$(b=-0.03 ; p=0.014)$. For AOPP we observed a relationship with peripheral Alx $(b=0.011 ; p=0.04)$ and sex. For the ox-LDL/LDL ratio, there were significant relations with $\mathrm{BMI}$, central pulse pressure $(b=0.053 ; p=0.008)$ and peripheral Alx $(b=-0.025 ; p=0.004)$ (Table 5). Moreover, there was a significant relationship between the SDMA/ADMA ratio and uric acid and eGFR in both hypertensives and normotensives $(b=-0.0061 ; p<0.0001$ and $b=-0.005 ; p<0.017$, respectively). Additionally, in hypertensives there was a relationship with peripheral pulse pressure $(b=-0.0067$; $\mathrm{p}=0.0143)$, and in normotensives SDMA/ADMA ratio was associated with uric acid $(b=1.3629 ; p=0.046)$.

\section{DISCUSSION}

Methylated arginines, ox-LDL or advanced oxidation protein products represent the set of markers recently widely investigated as potential measures of oxidative stress [13].

In our study we did not observe differences in ADMA, SDMA, ox-LDL or AOPP plasma levels between hypertensive and normotensive participants. Studies on oxidative stress markers in HT have provided varying results. Schlaich et al. [14] had similar results to ours. On the other hand, Surdacki et al. [15] observed an elevated ADMA concentration in newly diagnosed, not yet treated, hypertension. Perticone et al. [16] showed that the ADMA level is higher in hypertensives compared to a normotensive control group. Most studies by other groups have observed ADMA concentrations of approximately $2.6 \mu \mathrm{mol} / \mathrm{L}$ or more in hypertensives, such as would be found in end-stage renal disease or heart failure [17]. In our study, the mean ADMA concentration was $0.58 \mu \mathrm{mol} / \mathrm{L}$ in normotensives, and $0.56 \mu \mathrm{mol} / \mathrm{L}$ in hypertensives, much lower than in other studies. Schlaich et al. [14] also had lower concentrations of ADMA and SDMA in serum (for ADMA $1.11 \mu \mathrm{mol} / \mathrm{L}$ in normotensives without a family history of $\mathrm{HT}, 0.87 \mu \mathrm{mol} / \mathrm{L}$ in normotensives with a family history of $\mathrm{HT}$ and $1.61 \mu \mathrm{mol} / \mathrm{L}$; for SDMA $0.37 \mu \mathrm{mol} / \mathrm{L}$ in normotensives without a family history of $\mathrm{HT}, 0.55 \mu \mathrm{mol} / \mathrm{L}$ in normotensives with a family history of $\mathrm{HT}$ and $0.59 \mu \mathrm{mol} / \mathrm{L}$ in hypertensives). Our findings may be the result of the treatment of hypertensive patients with RAAS antagonists such as ACE inhibitors or ARB as these drugs have a proven effect on oxidative stress reduction.
Mizayaki et al. [2] found a positive correlation between the concentration of ADMA and mean BP in 118 subjects (40 with HT) without concomitant cardiovascular diseases. Moreover, Weber et al. [3] showed a negative correlation of ADMA with DBP on the brachial artery and in the aorta. In multivariate analysis, we did not however observe a relationship between ADMA and BP. In the group of normotensives, an independent relationship between ADMA and the central BP was observed. On the other hand, in multivariate analysis, as in the study by Weber et al. [3], we observed a negative correlation between DBP and the oxidative stress marker.

A recently published meta-analysis [18] showed that carotid-femoral PWV is an independent risk factor for death and cardiovascular death. Weber et al. [3] observed that ADMA levels in serum are associated with arterial stiffness estimated with central augmentation index (c Alx) as well as carotid-femoral PVW. The authors showed that in the whole cohort ADMA correlates with Alx and augmentation pressure [3], and that this correlation was significant for adults below as well as above the age of 60 . In our study, in multivariate analysis, the peripheral Alx correlated with AOPP in normotensives and an association between ADMA and PP p was present. In the Delles et al. study [19] comparing arterial stiffness in CAD patients to a control group, there was no difference in Alx (\%) between the two groups. There was a difference in terms of PWV and aortic compliance. Ox-LDLs were lower in the study group but the ratio ox-LDL/LDL was higher. In our study there was no difference between groups for ox-LDL/LDL but Delles et al. [19] investigated patients with CAD. Our patients had HT without CAD. Additionally, we did not observe a correlation between the oxidative stress markers and the superoxide anion production in the vascular wall [19]. However, in the study by Delles et al. [19], patients with CAD were treated with ACE inhibitors, statins. Delles et al. [19] showed a correlation between $\mathrm{O}_{2}$ production in the vascular wall and aortic compliance which persisted even after adjusting for classical risk factors. In multivariate analysis, we observed a positive correlation between AIx $\mathrm{p}$ and AOPP and a negative correlation for SDMA and ox-LDL/LDL ratio in normotensives. There was a positive correlation between ADMA and central pulse pressure in this group. The relation- 
ship between ox-LDL/LDL and arterial stiffness was shown in a group of young, middle-aged subjects and in the elderly $(n=2295)$ [20]. Brinkley et al. [20] observed that higher ox-LDLs are related to higher LDL and triglyceride, and that smoking, age, and drugs were not different in terciles of ox-LDL. The same investigators compared PWV in the same age category with high and low ox-LDL values and described higher arterial stiffness in the group with higher ox-LDL values.

Our study did not confirm the hypothesis that ox-LDL are markers of oxidative stress and are independent of other cardiovascular risk factors influencing arterial stiffness.

Zoccali et al. [5] observed that elevated ADMA were independent predictors of carotid IMT. Furuki et al. [21] showed that ADMA correlates with carotid IMT independently of BP, age and sex. In our observations in multivariate analysis the relationship between AOPP and IMT stayed significant in hypertensive patients. ADMA was also shown to be connected with IMT in healthy subjects, which suggests it is an important marker of atherosclerosis [2].

We suspected that antihypertensive pharmacotherapy may be one of the reasons why we did not observe any differences in oxidative stress markers between normotensives and hypertensives. Most of our patients were on drugs which inhibited the RAA system. These drugs have a proven effect on oxidative stress markers [22-24]. Additionally, several individuals were treated with statins or beta-blockers which also interfere with oxidative stress [25].

The novel findings of our study may throw some light on understanding the relation between organ damage and oxidative stress in HT and on understanding the role of methylated arginines or advanced oxidation protein products which may be significant in the search for new antihypertensive drugs.

\section{CONCLUSIONS}

We found that the influence of oxidative stress on the structure and function of large arteries is independent of HT. Therefore, oxidative stress may play a significant role in the development of arterial stiffness. Higher oxidative stress is associated with more advanced arterial remodelling in HT.

\section{Conflict of interest: none declared}

\section{References}

1. Rodgers AVP, Prentice T, Edejer TT-T, Evans D. The World Health Report 2002. World Health Organization, Geneva, Switzerland 2002.

2. Miyazaki H, Matsuoka H, Cooke JP et al. Endogenous nitric oxide synthase inhibitor: a novel marker of atherosclerosis. Circulation, 1999; 99: 1141-1146.

3. Weber T, Maas R, Auer J et al. Arterial wave reflections and determinants of endothelial function a hypothesis based on peripheral mode of action. Am J Hypertens, 2007; 20: 256-262.

4. Wojciechowska W, Staessen JA, Nawrot T et al. Reference values in white Europeans for the arterial pulse wave recorded by means of the SphygmoCor device. Hypertens Res, 2006; 29: 475-483.

5. Zoccali C, Benedetto FA, Maas R et al. Asymmetric dimethylarginine, C-reactive protein, and carotid intima-media thickness in end-stage renal disease. J Am Soc Nephrol, 2002; 13: 490-496.
6. Li D, Saldeen T, Romeo F et al. Oxidized LDL upregulates angiotensin II type 1 receptor expression in cultured human coronary artery endothelial cells: the potential role of transcription factor NF-kappaB. Circulation, 2000; 102: 1970-1976.

7. Kaneda $\mathrm{H}$, Taguchi J, Ogasawara K et al. Increased level of advanced oxidation protein products in patients with coronary artery disease. Atherosclerosis, 2002; 162: 221-225.

8. Kiechl S, Lee T, Santer P et al. Asymmetric and symmetric dimethylarginines are of similar predictive value for cardiovascular risk in the general population. Atherosclerosis, 2009; 205: 261-265.

9. Neisius U, Bilo G, Taurino C et al. Association of central and peripheral pulse pressure with intermediate cardiovascular phenotypes. J Hypertens, 2012; 30: 67-74.

10. Mancia G, De Backer G, Dominiczak A et al. 2007 Guidelines for the Management of Arterial Hypertension: The Task Force for the Management of Arterial Hypertension of the European Society of Hypertension (ESH) and of the European Society of Cardiology (ESC). J Hypertens, 2007; 25: 1105-1187.

11. Staessen J, Bulpitt CJ, O’Brien E et al. The diurnal blood pressure profile. A population study. Am J Hypertens, 1992; 5 (6 Part 1): 386-392.

12. Delles C, Schneider MP, John S et al. Angiotensin converting enzyme inhibition and angiotensin II AT1-receptor blockade reduce the levels of asymmetrical $N(G), N(G)$-dimethylarginine in human essential hypertension. Am J Hypertens, 2002; 15 (7 Part 1): 590-593.

13. Klima L, Stolarz Skrzypek K, Olszanecki R et al. The oxidative stress in pathogenesis of arterial hypertension - role of methylated arginines. Kardiol Pol, 2011; 69 (suppl. 3): 94-99.

14. Schlaich MP, Parnell MM, Ahlers BA et al. Impaired L-arginine transport and endothelial function in hypertensive and genetically predisposed normotensive subjects. Circulation, 2004; 110: 3680-3686.

15. Surdacki A, Nowicki M, Sandmann J et al. Reduced urinary excretion of nitric oxide metabolites and increased plasma levels of asymmetric dimethylarginine in men with essential hypertension. J Cardiovasc Pharmacol, 1999; 33: 652-658.

16. Perticone F, Sciacqua A, Maio R et al. Asymmetric dimethylarginine, L-arginine, and endothelial dysfunction in essential hypertension. J Am Coll Cardiol, 2005; 46: 518-523.

17. Kielstein JT, Bode-Boger SM, Frolich JC et al. Asymmetric dimethylarginine, blood pressure, and renal perfusion in elderly subjects. Circulation, 2003; 107: 1891-1895.

18. Vlachopoulos C, Aznaouridis K, Stefanadis C. Prediction of cardiovascular events and all-cause mortality with arterial stiffness: a systematic review and meta-analysis. J Am Coll Cardiol, 2010; 55: 1318-1327.

19. Delles C, Zimmerli LU, McGrane DJ et al. Vascular stiffness is related to superoxide generation in the vessel wall. J Hypertens, 2008; 26: 946-955.

20. Brinkley TE, Nicklas BJ, Kanaya AM et al. Plasma oxidized low-density lipoprotein levels and arterial stiffness in older adults: the health, aging, and body composition study. Hypertension, 2009; 53: 846-852.

21. Furuki K, Adachi H, Matsuoka $\mathrm{H}$ et al. Plasma levels of asymmetric dimethylarginine (ADMA) are related to intima-media thickness of the carotid artery: an epidemiological study. Atherosclerosis, 2007; 191: 206-210.

22. Chen JW, Hsu NW, Wu TC et al. Long-term angiotensin-converting enzyme inhibition reduces plasma asymmetric dimethylarginine and improves endothelial nitric oxide bioavailability and coronary microvascular function in patients with syndrome X. Am J Cardiol, 2002; 90: 974-982.

23. Ito A, Egashira K, Narishige $\mathrm{T}$ et al. Angiotensin-converting enzyme activity is involved in the mechanism of increased endogenous nitric oxide synthase inhibitor in patients with type 2 diabetes mellitus. Circ J, 2002; 66: 811-815.

24. Napoli C, Sica V, de Nigris F et al. Sulfhydryl angiotensin-converting enzyme inhibition induces sustained reduction of systemic oxidative stress and improves the nitric oxide pathway in patients with essential hypertension. Am Heart J, 2004; 148: e5.

25. Lu TM, Ding YA, Leu HB et al. Effect of rosuvastatin on plasma levels of asymmetric dimethylarginine in patients with hypercholesterolemia. Am J Cardiol, 2004; 94: 157-161. 


\title{
Wskaźniki stresu oksydacyjnego a struktura i funkcja tętnic $\mathrm{w}$ nadciśnieniu tętniczym
}

\author{
Łukasz Klima ${ }^{1}$, Kalina Kawecka-Jaszcz ${ }^{1}$, Katarzyna Stolarz-Skrzypek ${ }^{1}$, Jan Menne ${ }^{2}$, Kamil Fijorek ${ }^{3}$, \\ Agnieszka Olszanecka' ${ }^{1}$, Wiktoria Wojciechowska ${ }^{1}$, Grzegorz Bilo ${ }^{4}$, Danuta Czarnecka ${ }^{1}$ \\ II Klinika Kardiologii i Nadciśnienia Tętniczego, Collegium Medicum, Uniwersytet Jagielloński, Kraków \\ ${ }^{2}$ Klinika Nefrologii, Medyczna Szkoła Wyższa w Hanowerze, Hanower, Niemcy \\ ${ }^{3}$ Katedra Statystyki, Uniwersytet Ekonomiczny, Kraków \\ ${ }^{4}$ Klinika Kardiologii, Włoski Instytut Auksologii, Mediolan, Włochy
}

\section{Streszczenie}

Wstęp: Zależność między nadciśnieniem tętniczym a stresem oksydacyjnym nadal jest przedmiotem badań. Udowodniono, że reaktywne formy tlenu wpływają na ścianę tętnic oraz funkcję śródbłonka i w ten sposób mogą determinować wartość ciśnienia tętniczego.

Cel: Celem badania była ocena wybranych markerów stresu oksydacyjnego u pacjentów z nadciśnieniem tętniczym oraz ocena zależności między tymi markerami a wskaźnikami struktury i funkcji naczyń tętniczych.

Metody: Do badania włączono 217 osób (114 kobiet, 103 mężczyzn), pochodzących z rodzin, w których występowało nadciśnienie tętnicze. Średni wiek badanych wynosił 45,5 \pm 16 lat, u 155 osób rozpoznano nadciśnienie tętnicze. U każdego z uczestników wykonano pomiar prędkości fali tętna oraz ultrasonograficzną ocenę grubości kompleksu błony środkowej i wewnętrznej (IMT) tętnic szyjnych wspólnych. Jako wskaźniki stresu oksydacyjnego oznaczono asymetryczną dimetyloargininę (ADMA), symetryczną dimetyloargininę (SDMA), produkty zaawansowanej oksydacji białek (AOPP) i utlenowane lipoproteiny o niskiej gęstości (ox-LDL).

Wyniki: W analizie wieloczynnikowej wykazano, że u pacjentów z nadciśnieniem stężenie ADMA zwiększało się wraz ze wzrostem obwodowego ciśnienia tętna $(b=0,003 ; p<0,001)$, a AOPP wiązało się z wyższym wskaźnikiem IMT w tętnicach szyjnych $(b=0,91 ; p=0,036)$. Wśród osób z prawidłowymi wartościami ciśnienia zaobserwowano zależności między ADMA i centralnym ciśnieniem tętna $(b=0,006 ; p=0,008)$, SDMA i obwodowym wskaźnikiem wzmocnienia $(b=-0,03$; $\mathrm{p}=0,014)$, AOPP i obwodowym wskaźnikiem wzmocnienia ( $b=0,011 ; p=0,04)$, wskaźnikiem ox-LDL/LDL a obwodowym wskaźnikiem wzmocnienia $(b=-0,025 ; p=0,004)$. Wskaźnik SDMA/ADMA wiązał się z estymowaną filtracją kłębuszkową w obydwu grupach (odpowiednio: $b=-0,0061 ; p<0,0001$ i $b=-0,005 ; p<0,017$ ). U pacjentów z nadciśnieniem tętniczym zaobserwowano związek powyższego parametru z obwodowym ciśnienia tętna ( $b=-0,0067 ; p=0,0143)$. Ponadto u osób z prawidłowymi wartościami ciśnienia zanotowano zależność między wskaźnikiem SDMA/ADMA a stężeniem kwasu moczowego ( $b=1,3629 ; p=0,046)$.

Wnioski: Stres oksydacyjny wpływa na strukturę i funkcję naczyń tętniczych niezależnie od nadciśnienia tętniczego i może odgrywać istotną rolę w rozwoju sztywności tętnic.

Słowa kluczowa: stres oksydacyjny, sztywność tętnic, nadciśnienie tętnicze

Kardiol Pol 2013; 71, 9: 917-923 